\title{
The Histologic Effect of Baclofen in Rat's brain: An Experimental Study
}

\author{
Luma Ibrahim Khalel Al-Allaf ${ }^{{ }^{*}}$, Wahda M. Al-Neaimy ${ }^{2}$ \\ ${ }^{1}$ Department of Anatomy, Professor, ${ }^{2}$ Department of Pathology, College of Medicine, University \\ of Mosul, Mosul, Iraq. \\ Received Accepted \\ 5.11.2020 15.11.2020
}

Abstract

Background: Baclofen is the only clinically available metabotropic GABAB receptor agonist. Several reports has been discussed the efficacy of baclofen but the available data on its effect of the behavior and brains' histology are still limited.

Objectives: This work aims to assess the effects of long term exposure to baclofen (8weeks) on behavior and brains' histology in rats

Methods: Analysis of data of Twenty five healthy male Albino rats were performed. Rats weighing about 200-210 g with mean age of 65 days were randomly selected and categorized into three groups: Group 1(LD50 group): included five rats that gavaged with single dose of baclofen to test the LD50 of drug (145mg per $\mathrm{Kg}$ ) .Group 2. (control group):included eight rats were gavaged with distilled water for 2 months. Group 3.(baclofen group): included 12 rats gavaged with $15 \mathrm{mg} / \mathrm{kg}$ of baclofen (1/10th LD50) for 2 month. Behavioral Tests were conducted on all animals in group 2 and 3 including: Open-field test, Open -field habituation task ,and object recognition(Novel) to examine the influence of drug on the cognition of rats. All animals were euthanized with ether after 24hours of last day of treatment. Brains were excised and collected from rats of group 2 and 3.Fixation of tissues was done using buffered solution of ten percent of formalin for twenty four hours with paraffin wax embedding. Sectioning and staining by hematoxylin and eosin protocol (H\&E) and prepared to be examine histologically. To differentiate between the data of group 2 and 3 ,statistical analysis was performed by 1- way analysis of variance (ANOVA) .Least significant difference test with Duncan test was used . Value of $\mathrm{P}$ of equal or less than 0.05 means the difference is significant .

Results: This study revealed that the rats of baclofen group traveled a greater total distance(in both sessions) when compared with those of control indicating their hyperactivity. The zone specific analysis showed that the rats that were administered with baclofen consumed markedly greater time nearby the walls in the peripheral 
part in the arena throughout the first and $2^{\text {nd }} 15$ - min session in comparison with those of control group indicating the generalized hyperactivity and exploration. Rats of control group preferred the novel object in comparison with those of baclofen group. However there is no marked difference in the index of discrimination among rats of group 2 and 3. Histological sections of rats' brains in group that were administered with $15 \mathrm{mg} / \mathrm{kg}$ of baclofen for 2 month( baclofen group) revealed a diminished thickness in the pyramidal cells' layer, irregular faintly stained cells with shrinkage in the some pyramidal nerve cells, dark staining cytoplasm and losing the characteristics of their nuclei.

Conclusions:Chronic administration with baclofen $(15 \mathrm{mg} / \mathrm{kg} /$ day $/ 2 \mathrm{months})$ induces changes in the brain histology in rats, however, baclofen has no adverse effect on the behavior. To the best of our information, our work is the $1^{\text {st }}$ that focus on the influence of baclofen on both the behavior and brains' histology. Our data suggesting that baclofen may have clinical utility.

Keywords:_rat, brain, histopathology, baclofen, behavior.

\footnotetext{
التأثير النسيجى للباكلوفين لاى دماغ الجرذ :دراسة تجريبية

.

الخلقية: إن الباكلوفين هو الححفز المتوفر سريريا لمستقبلات كابا بيتا بضع من التقارير ناقثت الكفاءة للباكلوفين ولكن البيانات المتوفرة لتأثيره على السلوك ونسيج الدماغ لاتنز ال محدودة.

الاهداف: يهدف هذا العمل الى دراسة نأثير ات الاعطاء المزمن للباكلوفين لمدة ثمانية اسابيع على السلوك ونسيج الدماغ في

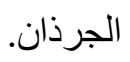

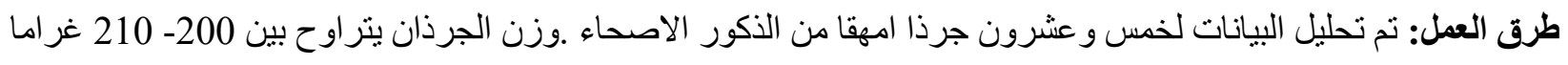

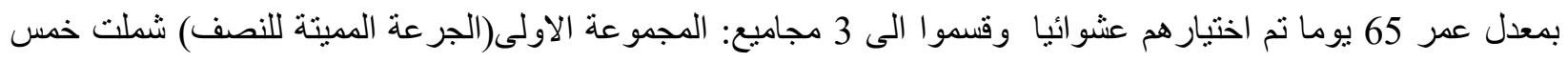

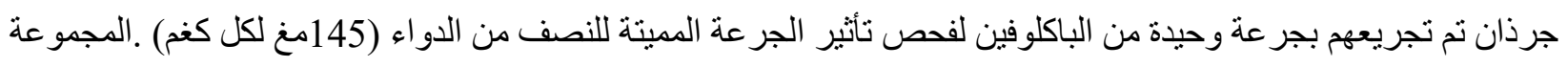
الثانية (مجموعة السيطرة)تثمل ثماني جرذان تم تجريعهم بالماء المقطر لمدة شهرين.المجموعة الثالثة (مجموعة الباكلوفين)

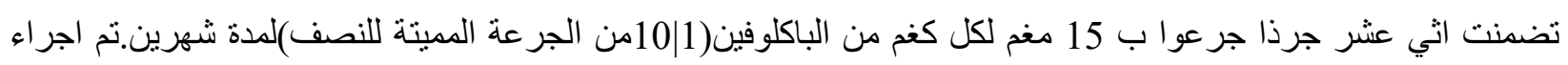
فحص السلوك لكل الحيو انات في المجمو عة الثانية والثالثة ويثمل ذللك: فحص الحقل الكفتوح, فحص الحقل الدفتو حل لمهمة التعود,
} 
فحص تمبيز الجسم المستجد لفحص تأثير الدواء على الادرالك في الحيوانات. نم اجر اء القتل الرحيم بالايثز بعد 24 ساعة من اخر يوم من العلاج. تم استئصال الادمغة وجمعه من المجموعة الثانية والثالثة وتثبيتهم بمحلول الفورمالين المتعادل بتركيز 10\% لمدة 24 ساعة ووضعهم بشمع البار افين ثم تم قصهم وصبغهم بالهيماتو كسيلين ايوسين للفحص النسيجي .تم تحليل الاختلاف بين المجمو عتين التجريبيتين احصائيا بواسطة تحليل المتغير ات ذو الطريق الواحد متبعا بالفارق المعنوي الاصغر واختبار دنكن حيث كان مستوى قيمة ب يعتبر معنوي عندما تكون اقل من 0.05. النتائج: اظهرت هذه الدر اسة ان الجرذان لأى مجموعة الباكلوفين عبروا مسافة اكبر في كلا الثوطين بالمقارنة مع مجموعة السيطرة مما يدل على نشاطهم العالي. ان التحليل الخاص بالمنطقة اظهر ان الجرذان المعاملين بالباكلوفين قضوا وقتا اطول قرب الجدران في المنطقة الخارجية في الساحة خلال الشوط الاول والثاني الذي استغرق كل منهما15 دقيقة بالمقارنة مع مجمو عة السيطرة مما دل على النشاط العالي والاستكثاف.ان جرذان مجموعة السيطرة فضلوا الجسم الجديد بالمقارنة مع اولئك العائدين لمجمو عة الباكلوفين.ومه هذا كان الاختلاف في معيار التمييز بين المجموعتين غير معنوي.ان فحص النسيج الدماغي للجرذان الذين جر عوا بالباكلوفين (15مغم لكل كغم) لشهرين ـمجموعة الباكلوفين لوحظ فيه نقصان في ثخن الخلايا الهرمية وورجود خلايا غير منتظمة وذات صبغة فاتحة اللون مع خلايا هرمية عصبية منكمشة مع سايتو بلازم غامق ونقص في تفاصيل النواة. الاستتناجات:ان الاعطاء المزمن بالباكلوفين( 15مغم لكل كغم|يوم |شهرين)احدث تغييرات في نسيج الدماغ لدى الجرذان مع العلم انه لم تكن هنالك تاثير ات عكسية ملحوظة على سلوكهم.حسب معلوماتنا هذا اول بحث حاول دراسة تاثير الباكلوفين على كلا السلوك ونسيجية الدماغ.نتائجنا تقتر ح امكانية الاستفادة من الباكلوفين سريريا. الكلمات المفتاحية.الجرذ,الدماغ, النسيجية المرضية, الباكلوفين,السلوك

INTRODUCTION

$\mathrm{T}$ he receptors of Gammaaminobutyric acid B GABABacts metabotropically and chiefly to inhibit central nervous system (CNS) of mammals.

Beta-chlorophenyl-GABA (baclofen, Lioresal) is the only clinically obtainable GABA beta receptor agonist and it is used as the first-line treatment for rigid skeletal muscles and spasticity beyond traumatic injured spinal cord, cerebral palsy, multiple sclerosis, and amyotrophic lateral sclerosis ${ }^{(1)}$ beside its analgesic effects.

Little portion of this drug exclusively can crosses the blood-brain barrier, inducing the wanted effects ${ }^{(2)}$.

The generalized depression of CNS influences can results into fatigability, syncope, ataxic gate, low blood pressure, disturbances in psychology, and depression in both respiratory cardiovascular functions ${ }^{(3)}$. 
The receptors of Gammaaminobutyric acid B are commonly scattered within the CNS. They are fully distributed in hippocampal region which acts crucially for memory and spatial (locative) learning (4) .There have been studies on GABAB receptor ligands and their participation in learning and memory processes $^{(5)}$.

The effect of GABAB receptors agonists on cognitive processes using animal models have turned out to be rather inconsistent. Laboratory animal studies have reported that baclofen disrupts ,(in dose dependent manner), memory and learning in rodents after systemic intake (followed by behavioral testing e.g. avoidance condition test ${ }^{(6)}$ Morris water maze test ${ }^{(7)}$ ).Memory impairment has been described for oral administration of baclofen that leads to the incapability in remembering or recognition of familiar persons' names, locations and also for intrathecal administration ${ }^{(8,9)}$. Baclofen facilitates abstinence in chronic alcoholics, so that lead to an exponential raised its use at high doses and that may be the cause of mounting intoxication. In fact, baclofen toxicity is an under diagnosed emergency $^{(10)}$.The precise pathways that stands behind the neuro-toxicity after using of overdose of baclofen are still unclarified as the studies are unsatifactory .

The rat model surely propagated humans' baclofen toxicities that is threatening their lives ${ }^{(11)}$. Behavioral impairments, sleeping disturbances, and impairments in the activity of electroencephalograph are reported in the rats after administration with single / repeated dose of baclofen less than 20 $\mathrm{mg} / \mathrm{kg}{ }^{(12)}$.

On the other hand, a recent study showed that long term stimulation of GABA Beta receptors ameliorates the achievements on a multiple of cognitive and social duties that is shown to be diminished in 2 various mouse models of $16 \mathrm{p} 11.2$ deletion that were suggested to permit risks for autism spectrum disorder and intellectual disabilities which influences on about 3 in 10000 people (13).

There is a paucity on the influence of long time exposure to baclofen on the cognitive function and brain structure in rats. The target of this research was to analyze the impact of prolonged administration with baclofen on behavior and brain histology in rats in order to discuss its contribution to the neurotoxicity -if -present. 
MATERIALS and METHODS

\section{Animals}

Twenty five rats (Albino, male and healthy )were purchased from Animal House of Veterinary College, University of Mosul, Mosul, Northern Iraq.

Rats weighing about 200-210 g with mean age of 65 days. All of them were kept under well-controlled normal environmental and laboratory situations and animal facility and they were put separately in Animal House plastic cages (North Kent, England) measuring $47 \times 34 \times 18 \mathrm{~cm}$ filled from inside with wood chips ${ }^{(14)}$.Animals were prepared to acclimatize and left free for ten days before start any experiment ${ }^{(15)}$,and will be supplied with free access of water ad libitum and packed optimized rodent chow ${ }^{(16)}$. The procedures were conducted according the roles of the careful laboratory animals' usage with obtaining the approval of the Ethical Committee of College of Medicine ,Mosul University, choosing of few number of rats to gain the convenient results with avoiding of pain and stress. All experiments were conducted during the 12hours- light part ${ }^{(17)}$.Rats were randomly selected and categorized into three groups $^{(2)}$ : Group 1(LD50 group) included five rats that gavaged with single dose of baclofen to test the effect of LD50 of drug (145mg per Kg) ${ }^{(18,19,20)}$. Observation of animals for any signs of manifestations of acute toxicities beside that of LD50 mortalities.

Group 2. (control group) included eight rats were kept quietly in a group without any stress, received distilled water for 2 month via gavage needle

Group 3.(baclofen group) included 12 rats gavaged with $15 \mathrm{mg} / \mathrm{kg}$ of baclofen (one tenth of LD50) in gradual raised doses for 2 months ${ }^{(21)}$.

Baclofen was obtained from some private pharmacies.

After drug dissolving in distilled water and it was gavaged orally via 24 gage needle. The rats were properly restrained to stabilize the head and kept in a vertical position. The gavage needle were appropriately fixed on Mantoux syringe and introduced through the side of the mouth, observed the roof of the mouth, and passed into the esophagus toward the stomach ,then the baclofen were injected ${ }^{(22)}$.

Each treated animal was monitored for unconcealed signs of toxicity for the next four hours, and mortality throughout the next 24 hours. Then rats of groups 2 and 3 were submitted to the behavioral tests after 24hours of last day of treatment as the following: 
Behavioral Test: It was performed in the following sequences :

\section{Open-field test}

This test is frequently utilized to evaluate anxiety and activity of locomotor system liking behaviors in experimental studies ${ }^{(23)}$. A box of wood with $40 \times 40 \times 40 \mathrm{~cm}^{3}$ dimensions with fund divided to equal 25 squares was used to measure parameters throughout 5 minutes ${ }^{(24,25)}$.

\section{Open -field habituation task}

In the same previously mentioned box, this test was used during two sessions 15-min/ each, spaced 1-2 h apart. Animals were kept in the container of behavior and permitted for free explorer throughout each habituation's session. Sessions were registered and locomotor actions was observed. To analyze the data, the box was categorized into 2 zones: the 'inner' one (including the inner $30 \times 30 \mathrm{~cm}^{2}$ central square) and an 'outer' one (the most peripheral area $5 \mathrm{~cm}$ from the margins). Computing the overall distance passes with the summation of distance of overall the course of each habituation's session.

\section{The test of novel recognition of object}

The test of novel recognition of object was done according to that of Leger et al, $2013^{(26)}$. rats were accommodated to a $40 \times 40 \times 40 \mathrm{~cm}^{3}$ box throughout $2 \times 15$-minutes sessions, with space of 1-2 hr. in between. In between session, rats were brought back to the home cages. A day (24 hr. ) beyond habituation, in the same box, rats were allow for exposure to two similar objects for $2 \times 10$ minutes exploring sessions with space of $1-2 \mathrm{~h}$ in between. Rats were demanded for the exploration of each object I a period of $10 \mathrm{~s}$ ( overall of $20 \mathrm{~s}$ ) in the $1^{\mathrm{st}}$ session to be enrolled in the consequent sessions. A day (24 hr.) after exploration of object, one object replacement with a novel one and the rats were permitted for the objects' exploration within 10 minutes. Recording of the time expended for exploration was performed throughout this exploring duration and was manifested by sniffing from $2 \mathrm{~cm}$ of each object or by direct touch of the objects. Excluding of the time expended on the object's top or climbing. Random assignment of both novel and familiar objects with the area of placement was done, by rat. 
Calculation of index of discrimination using the following equation :

Time expended for exploration novel object /time expended for novel object's exploration +time expended for exploration of familiar object.

\section{Histopathological Analysis:}

At the last day of the designed work, all animals were euthanized with ether (14)after 24hours of last day of behavioral tests at the laboratory of Physiology , College of Dentistry, University of Mosul. All experimental works were conducted as the experimenter blind to protocols. Brains were excised collected from rats of all rats in a careful way during infectious precautions ${ }^{(17)}$ and they were immediately weighed and examined macroscopically before they will be immersed in $\mathrm{NaCl}$ solution $0.9 \%$ for

\section{RESULTS}

All rats were survived all the experimental work .This study were analyzed the behavioral and histopathological data of 20 rats of group 2 and 3 blindly.

\section{Locomotor activity :}

Regarding the tests of behavior ,observations of rats' locomotor activity of the current study revealed that the rats that were administered with baclofen showed no marked few seconds in order to get rid of superficial blood and fixation via solution of ten percent buffered formalin was done for $24 \mathrm{hr}$. and paraffin embedding. Sectioning and staining with hematoxylin and eosin protocol (H\&E) to be examined histologically via light microscopical technique. Grading of tissue was recorded according to that described previously ${ }^{(2,27)}$.

Statistical analysis :Data were manifested as mean $\pm \mathrm{SD}$, analysis of statistical difference among the experimental groups were done by 1 way analysis of variance (ANOVA) .Following that the least significant difference test and Duncan test was performed. P- Value of equal or less than 0.05 was considered as significant $^{(28)}$.

difference in their findings of open field locomotor activity in comparison with control group, however the rats which received baclofen exhibited some features of hyperactivity.

\section{Open field habituation:}

To examine the habituation in this condition, recording of the rats' activity of both groups across two 15min recording sessions, spaced $1-2 \mathrm{~h}$ apart. During each habituation session, monitoring of activity inside a $40 \times 40$ 
$\mathrm{cm}^{2}$ container was done to identify the time expended in the 2 identified outer and inner zones of the field of behavior during sessions .

This study revealed that the rats that were administered with $15 \mathrm{mg} / \mathrm{kg}$ of baclofen for 2 month(baclofen group) traveled a greater total distance (in both sessions) when compared with those of control indicating their hyperactivity (Figure 1a).

Across all treatments, rats spent equal period in context's exploration time throughout the $2^{\text {nd }}$ recording session in comparison with the first session.

The zonal specified analyses showed that the rats that were administered with baclofen (baclofen group) expended markedly more time nearby the margins in the peripheral zone (of the arena) throughout the first and $2^{\text {nd }}$ 15- minutes session in comparison with those of control group indicating the generalized hyperactivity and exploration(Figure 1b).

\section{Object recognition:}

This study examined the effect of treatment with baclofen via an object's recognition memories test as rats were permitted for the arena's exploration using 2 similar objects in paired 10min sessions of exploring with a space of 1-2 hr. in between. After a day (24 hrs.), one of these objects was substituted by a new object and an index of discrimination was estimated as (time expended in novel object's sniffings)/(overall time expended in the novel's sniffing +familial object) during a ten minutes investigating session .The rats of control group preferred the novel object in comparison with those of baclofen group. However, no marked differences in the index of discrimination between both groups(Table 1).

The current study revealed that the rats of both groups spent more time for the familiar object and they have not preferred for the novel object.

\section{Histopathological Analysis:}

This study revealed that the histopathological observations of sections of control animals showed normal structures of the brain including the polymorphic, pyramidal, and molecular layers. The neurons (pyramidal cells ) appeared as big and has a shape of triangle as shown in Figure 2a \&b.

When examining the brain tissue of the rats that were administered with $15 \mathrm{mg} / \mathrm{kg}$ of baclofen for 2 month(baclofen group) ,there is diminishing of the pyramidal layer's thickness, irregular faintly stained cells with pyramidal nerve cells' 
shrinkage with dark staining

cytoplasm beside loosing details of

nuclei (Figure 3a,b,c).

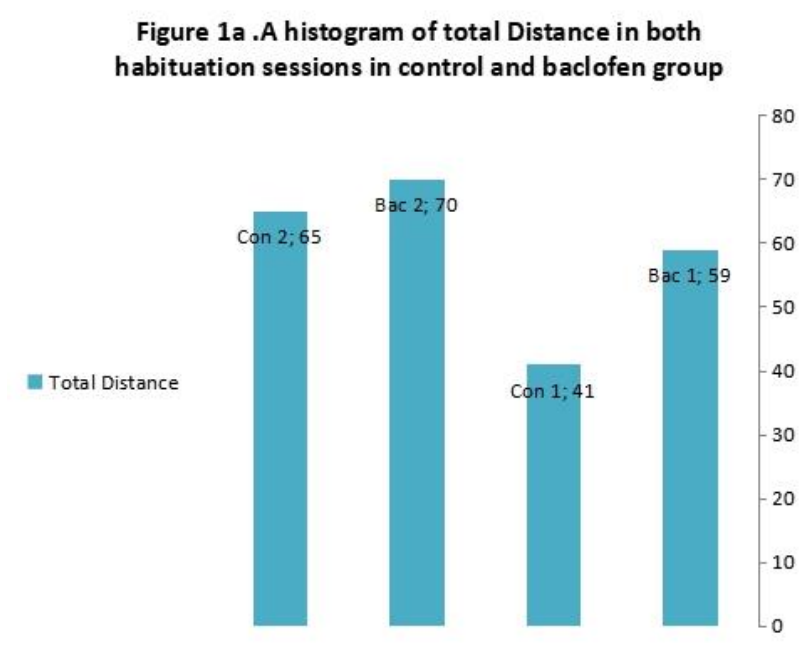

*Con 1 , the total distance in the first session in control rats ; Con 2, the total distance in the second session in control rats ; Bac 1, the total distance in the first session in rats of baclofen group; Bac 2 , the total distance in the second session in rats of control group.

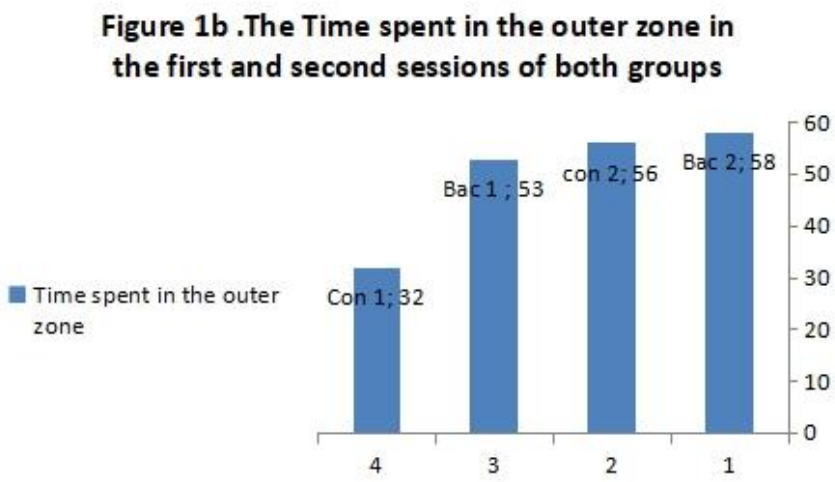

*Con 1, the time expended in the peripheral region in control rats in the first session; Con 2, the time expended in the peripheral region in control rats in the second session; Bac 1, the time expended in the peripheral region in the in rats of baclofen group in the first session; Bac 2, the time expended in the peripheral region in rats of baclofen group in the second session. 
Table 1.A comparison between the Discrimination Index in both control and Baclofen Groups using Object recognition test.

\begin{tabular}{|l|l|l|l|}
\hline Groups & Control Group & Baclofen Group & P-Value \\
Discrimination Index & & $\mathrm{N}=12$ & \\
\hline & & & \\
\hline
\end{tabular}

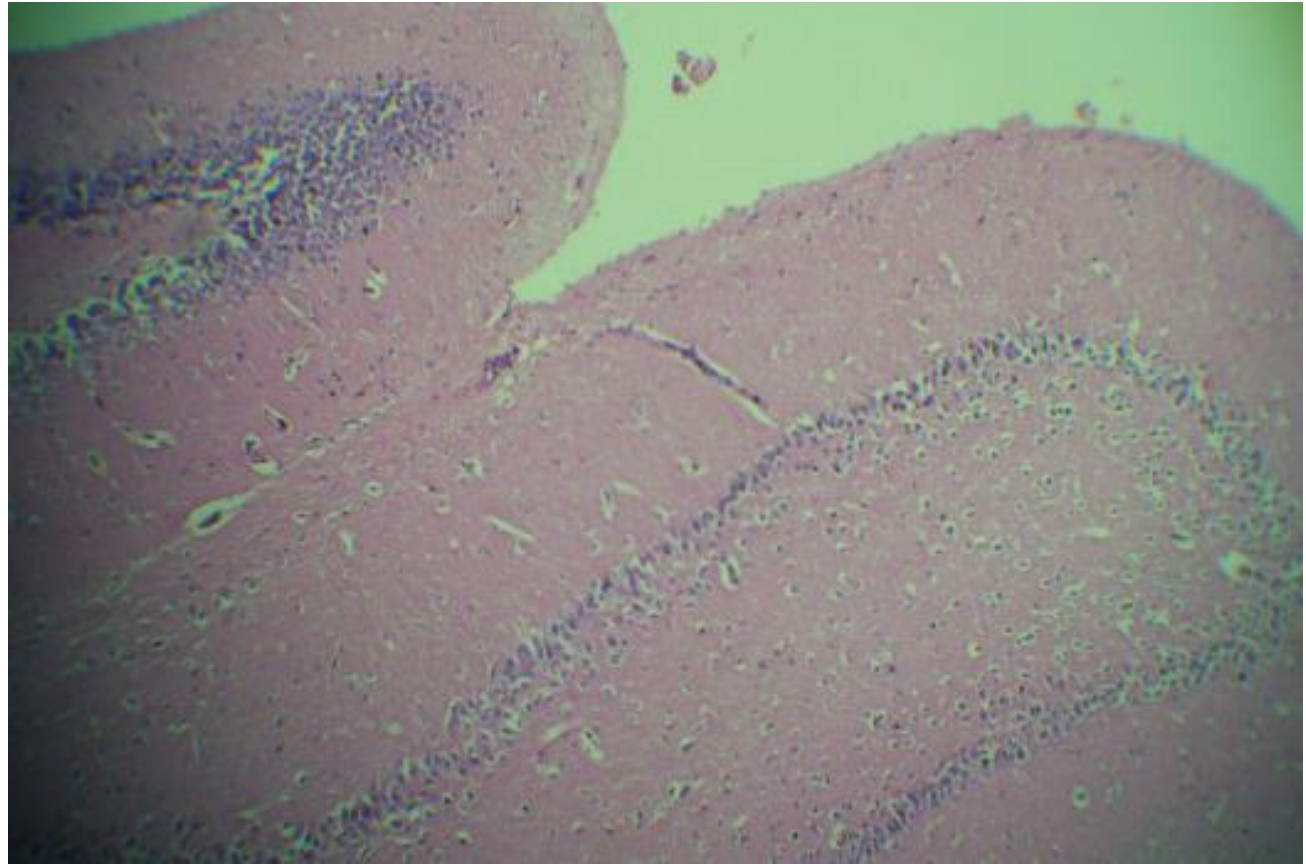

Figure 2a.A photomicrograph of a brain section from rat of control group with normal architecture of the brain tissue of polymorphic, pyramidal, and molecular layers. (H\&E× 250). 


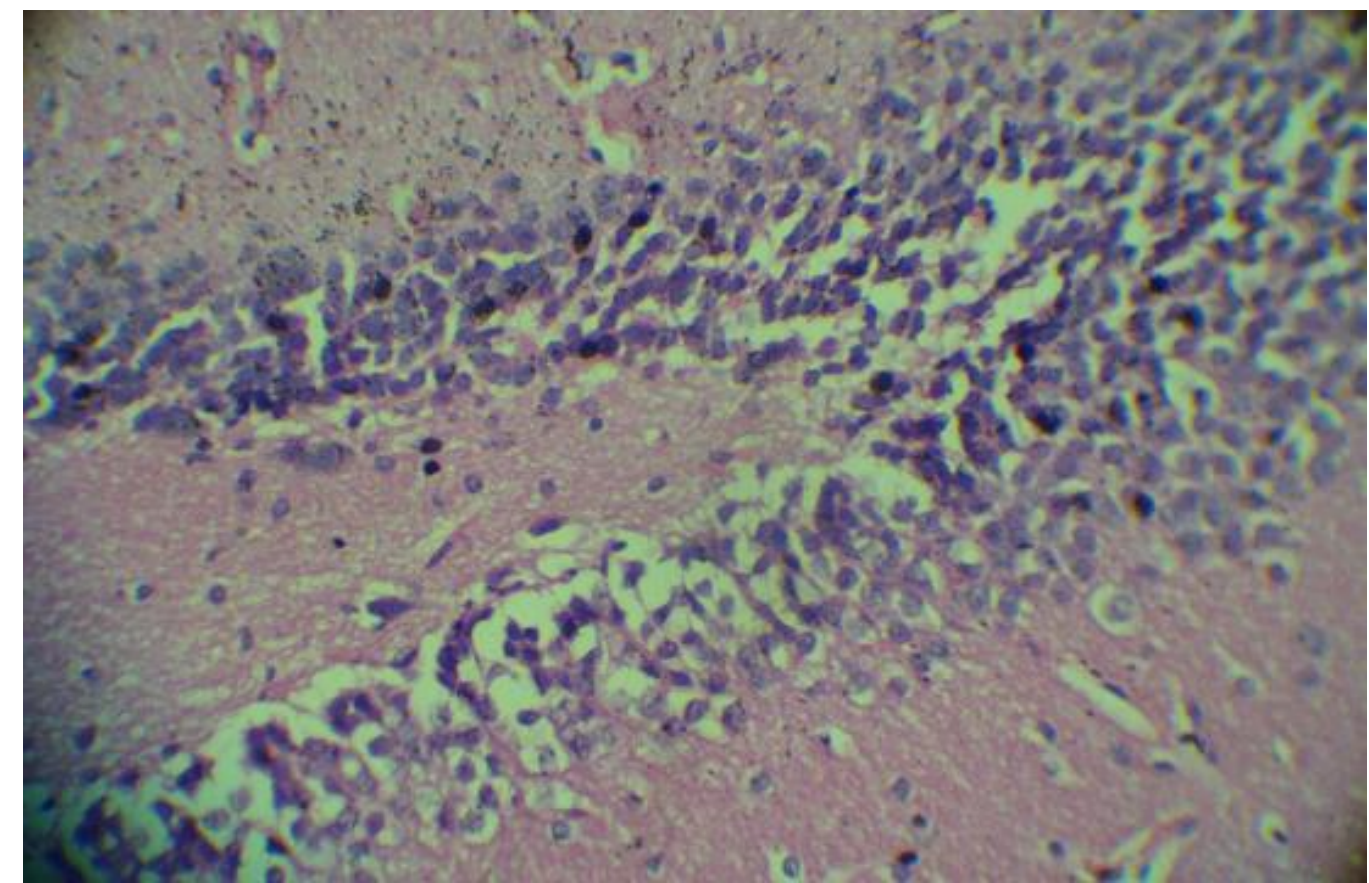

Figure 2b.A photomicrograph of a section from brain of control rat with normal architecture of the brain tissue. The big triangular pyramidal nerve cells are noticed(H\&E×400).

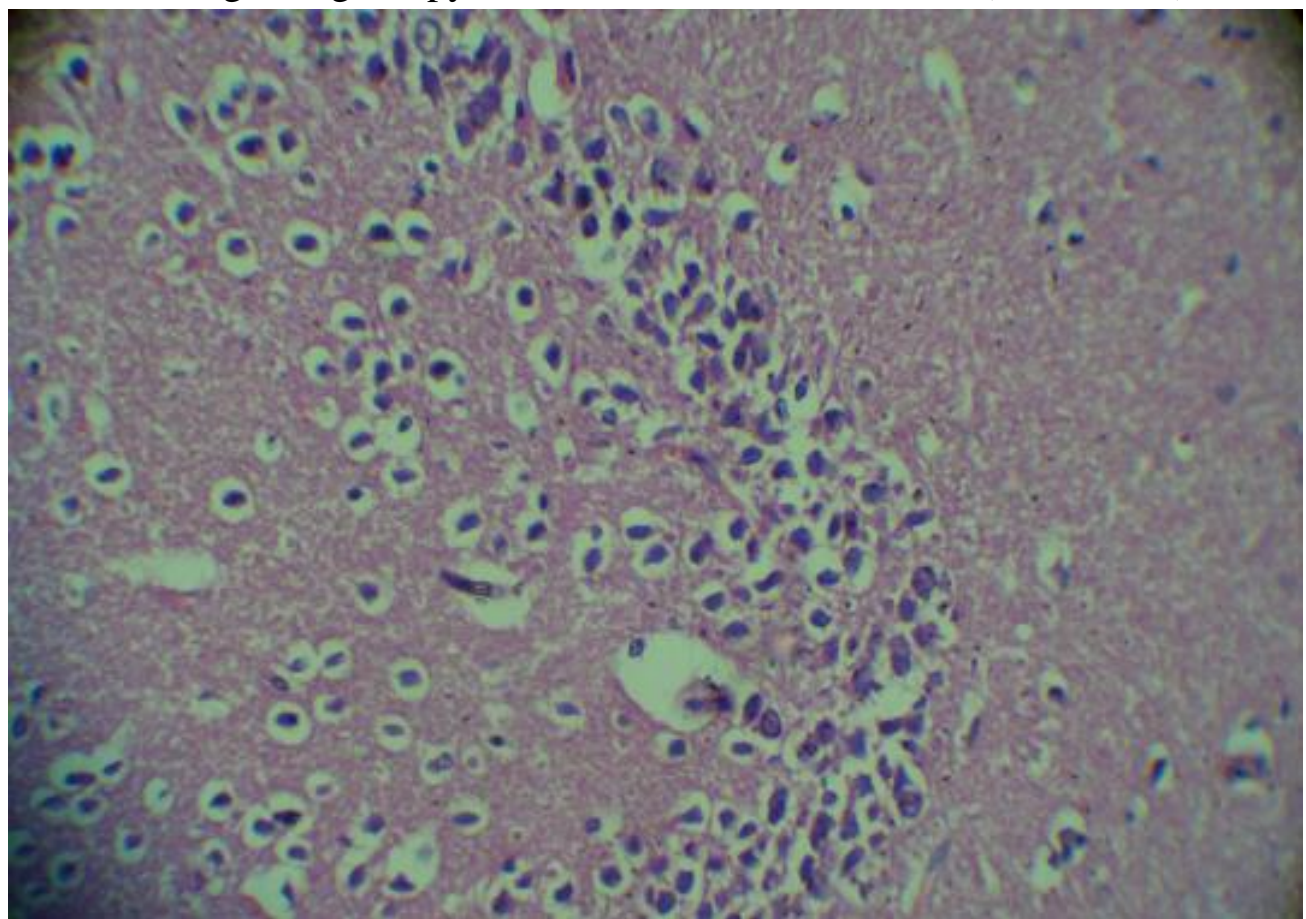

Figure 3a.A photomicrograph of a brain of rat that were administered with $15 \mathrm{mg} / \mathrm{kg}$ of baclofen for 2 month (baclofen group) with decreased thickness of pyramidal cell layers.(H\&Ex400). 


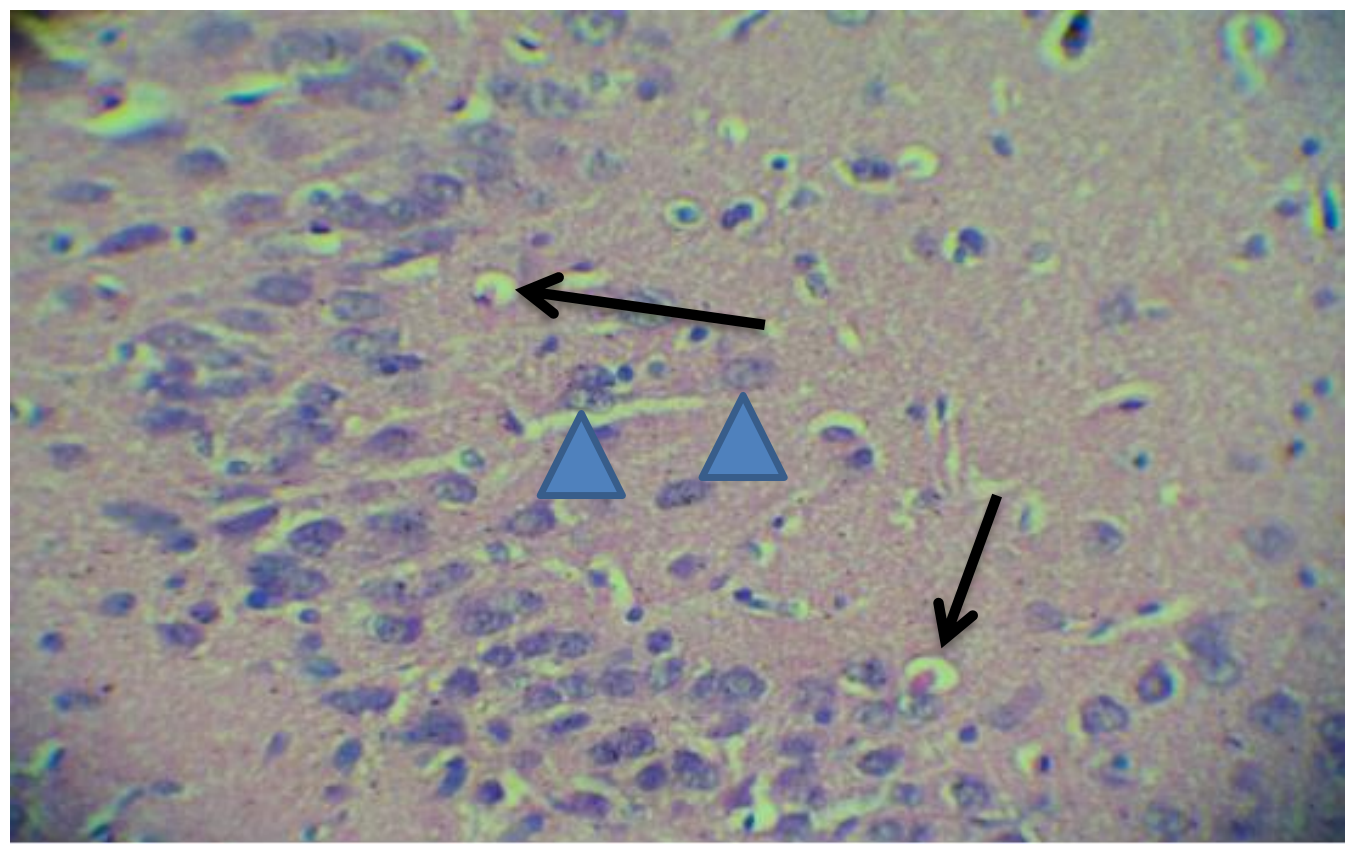

Figure 3b.A photomicrograph of a brain section from rat of baclofen group with diminished pyramidal layer's thickness, irregularly faint cells and other nerve cells with vesicles in nuclei and obvious nucleoli(arrow heads) and pyramidal neurons' shrinkage with a dark staining cytoplasm and losing the details of nuclei (arrow) $(\mathbf{H \& E \times 4 0 0 )}$.

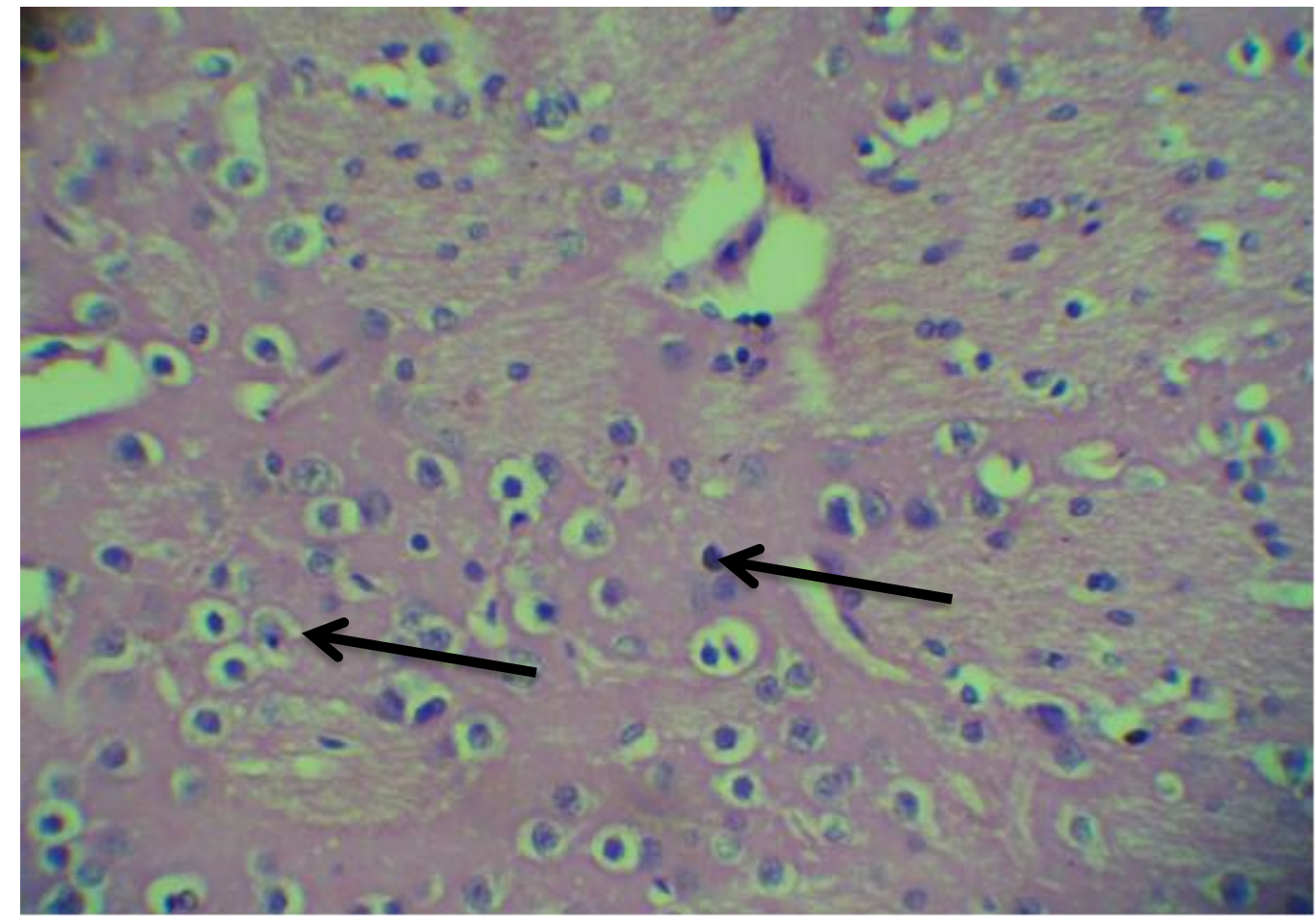

Figure 3c .A photomicrograph of a section of the rat's brain of baclofen group. Shrunken eosinophilic neurones with pyknotic nuclei(arrow)(H\&E×400). 


\section{DISCUSSION}

The current study analyzed the effect of chronic administration of rats with $15 \mathrm{mg} / \mathrm{kg}$ of baclofen for 2 months on the behavior and the brain histology. Rats of baclofen group showed mild features of hyperactivity using locomotor test according to the parameters of Moser et al. and of Molingo et al. ${ }^{(24,25)}$.During open field habituation test, the chronic administration with baclofen leads to hyperactivity as the total distance was greater in rats treated with baclofen compared to those of control rats. Our findings are in accordance with those of Stoppel et al. ${ }^{(13)}$. Moreover, the zone specific analysis revealed that rats treated with baclofen explored the outer zone more than the inner one when compared to those of control indicating features of an increased exploring.

Depending on the observations of the previous experiment which proposed that GABA-B receptors' activation could emerge the contrast in neuronal excitation in some zones of the brain $^{(29)}$. The anxiolytic influence of baclofen may reflect stimulation of GABA-B receptors of amygdala ${ }^{(30)}$. Object recognition test was done in this study and it revealed that rats of control group preferred the novel object in comparison with those of baclofen group. However ,non significant differences among the index of discrimination of both groups. Moreover, the current study revealed that the rats of both groups spent more time for the familiar object and without a predilection of the new object. These observation are in accordance with those of other authors who reported that Vehicle-treated Wild type mice strongly preferred the novel object, and they observed that the prolonged intake of R-baclofen had no influence on predilection of novel object in these mice ${ }^{(13)}$. Their data suggested that $\mathrm{R}$ baclofen may be useful for management of phenotypes of cognition in influenced human.

Histopathologic observations in this work research revealed some findings of brain tissues characterized by shrinkage of neurons with esinphelia and nuclear pyknosis in the cerebral cortex in rats of baclofen group, while controls showed normal brain histopathology. These observations were similar to those of others ${ }^{(2,21)}$. Penetration of the blood-brain barrier by baclofen lead to depressive neuronal activities in the central nervous system. In spite of the fact that baclofen's serum concentration is more than in brain, but its' elimination 
from CNS is slower than that from serum. The depression of CNS , for that reason remains for several days, also beyond the returning of plasma baclofen levels to normal values which indicates marked neurotoxicity ${ }^{(31)}$.The raised lipophilic nature of baclofen is explaining the prolongation in coma after administration of its overdose ${ }^{(32)}$.However, another study revealed that baclofen administration for 4 weeks did not induce any structural changes in the rats ${ }^{(21)}$. The difference between the findings of that work and our study may be the difference in the duration of exposure to baclofen.

In conclusions: Chronic administration of rats with baclofen $(15 \mathrm{mg} / \mathrm{kg} / \mathrm{day} / 2$ months $)$ induces changes in the brain histology, however, baclofen has no adverse

\section{ACKNOWLEDGMENTS}

Authors would like to thank all members of Department of Anatomy, Veterinary College, University of Mosul for facilitating the work. We are grateful to Dr. Amjad Al-Naemi for his useful comments. Thanks to assistant lecturer Basma Saad Allah,

\section{REFERENCES}

\section{1}

.Bettler B, Kaupmann K, Mosbacher J, Gassmann M: Molecular structure and effect on their behavior. According to our knowledge, this work is the $1^{\text {st }}$ that tries to clarify the influence of baclofen on both the behavior and brains' histology. Our data suggesting that baclofen may have clinical utility as there is a need to make a good adjustment of the dose and careful monitoring especially when it was given for long duration. In addition, small doses of baclofen may be used in future to improve cognition.

\section{Limitations of the study:}

Several limitations were faced throughout this work. One of them is absence of well-equipped laboratory or place for testing of the behavior of rats in our College , and lack of advanced camera to recording their behavior especially at night.

Department of Basic Sciences, College of Dentistry, University of Mosul, for her help. Finally, We thank Professor Dr. Ghada Taqa ,Department of Basic Sciences ,College of Dentistry, University of Mosul, for her advises. 
physiological functions of GABA(B) receptors. Physiol Rev.2004; 84: 835867.

2. Issa SY, Hafez EM, El-Banna AS ,Abdel Rahman SM, AlMazroua MK and El-Hamd MA. Baclofen systemic toxicity:

Experimental histopathological and biochemical study. Human and Experimental Toxicology.2018; 37(4) :431-441.

3.Dario A and Tomei G. A benefit-risk assessment of baclofen in severe spinal spasticity. Drug Saf. 2004;27(11): 799-818.

4.Benarroch EE: GABAB receptors: structure, functions, and clinical implications. Neurology . 2012;78: 578-584.

5. Bowery NG, Bettler B, Froestl W, Gallagher JP, Marshall F, Raiteri M, Bonner TI, Enna SJ: International Union of Pharmacology. XXXIII. Mammalian gamma-aminobutyric acid(B) receptors:structure and function. Pharmacol Rev. 2002; 54: 247-264.

6.Castellano C, Mcgaugh JL: Oxotremorine attenuates retrograde amnesia induced by post-training administration of the GABAergic agonists muscimol and baclofen. Behav Neural Biol . 1991;56: 25-31. 7.Nakagawa $\mathrm{Y}$, Takashima T: The $\mathrm{GABA}(\mathrm{B})$ receptor antagonist CGP36742 attenuates the baclofen- and scopolamine-induced deficit in Morris water maze task in rats. Brain Res. 1997 ; 766: 101-106.

8.Sandyk R, Gillman MA: Baclofeninduced memory impairment. Clin Neuropharmacol. 1985; 8: 294-295.

9. Grande LA, Loeser JD, Samii A: Recurrent transient global amnesia with intrathecal baclofen. Anesth Analg. 2008;106: 1284-1287.

10. Chartier M, Tannous S, Benturquia N, Labat L, Reis R, Rise`de P, Chevillard L, M_egarbane B. Baclofen-Induced Neuro-Respiratory Toxicity in the Rat: Contribution of Tolerance and Characterization of Withdrawal Syndrome. Toxicological Sciences. 2018 ; 164(1): 153-165.

11.Franchitto N, Pelissier F, Lauque D, Simon N, and Lanc on C. Selfintoxication with baclofen in alcoholdependent patients with co-existing psychiatric illness: an emergency department case series. Alcohol. 2014 ; 49:79-83.

12.Hodor A, Palchykova S, Gao B, and Bassetti C. L. Baclofen and gammahydroxybutyrate differentially altered behavior, EEG activity and sleep in rats. Neuroscience. 2015; 284: 18-28. 13. Stoppel LJ, Kazdoba TM,Schaffler MD, Preza AR, Heynen A , Crawley JN , Bear MF.R-Baclofen Reverses Cognitive Deficits and Improves Social Interactions in Two Lines of 
16p11.2 Deletion Mice Neuropsychopharmacology.2018; 43: 513-524.

14. Favareto APA, Fernandez CDB, Fossato da Silva DA, et al. Persistent impairment of testicular histology and sperm motility in adult rats treated with cisplatin at peripuberty. Basic Clin Pharmacol Toxicol. 2011;109:8596.

15. Ilbey YO, Ozbek E, Cekmen M, et al. Protective effect of curcumin in cisplatin-induced oxidative injury in rat testis: mitogen-activated protein kinase and nuclear factor-kappa B signaling pathways. Hum Reprod. 2009;24(7):1717-1725.

16. D‘Souza UJA. Toxic effects of 5fluorouracil on sperm count in Wistar rats. Malaysian $\mathrm{J}$ Med Sciences. 2003;10(1):43-45.

17.Al-Allaf, L.I.K.; Al-Ashoo, H.A. The effects of imatinib on the testicular histology in male rats administered at peripubertal period. JABHS. 2014; 15(1): 24-34.

18. Ld50 Kenkyu, I. Baclofen LD50. Study Med Supp. 1980; 11: 181.

19. LD50Cayman chemicals (2015). Safety Data Sheet: (6)-Baclofen. Available at: https://www.caymanchem.com/msdss / 18600m.pdf. Accessed March 27, 2018.
20.Material Safety Data Sheet Baclofen MSDS last updated at 2012 by science lab for chemical and laboratory equipment, www.sciencelab.com/msds.

php?msdsId $1 / 49922994$

(2013, accessed 22 February2017).

21. Ghada E. Elmesallamy1 and Nermeen R. Abdel Fattah. Toxicological evaluation of the neuroendocrinologic, pancreatic and hepatic effects of baclofen in alcohol dependent albino rats Z.U.M.J. 2013;19(1): 14-26 .

22. Nurmio M, Kallio J, Toppari J, Jahnukainen K.Adult reproductive functions after early postnatal inhibition by imatinib of the two receptor tyrosine kinases, c-kit and PDGFR, in the rat testis. Reprod Toxicol . 2008 ;25(4):442-446.

23. Lowery CA, Johnsen PL, HagSchmidt A, Mikelsen J, Shekhar A. Modulation of anxiety circuits by serotonergic system. Stress .2005; 8:233-246.

24.Moser VC, Mclormick JP, Greason JP, Macphail RC .Comparison of chlordime form and carbaryl using a functional observational battery Fund Appl. Toxicol. 1988; 11:189-206.

25.Molinengo L and Fundaro A. The effect of chronic atropine administration on mouse motility and on Ach levels in the central nervous 
system. Pharmacol. Biochem. Behave. 1989; 32:1075-1077.

26. Leger M, Quiedeville A, Bouet V, Haelewyn B, Boulouard M, Schumann-Bard $\mathrm{P}$ et al. Object recognition test in mice. Nat Protoc. 2013; 8: 2531-2537.

27.V Wilson, I. and Gamble, M. (2002): The hematoxylins and eosins, In: Theory and practice of histological techniques, Bancroft JD and Gamble M (eds.), 5th ed., Churchill Livingston, Elservier Science Limited, London, UK, pp. 125-138.

28. TAQA GA .Evaluation of antidepressant activity of diphenhydramine in mice..Innovare Journal of Medical Science. 2013; 1( 2): $15-18$.

29.Fujita S, Koshikawa $\mathrm{N}$ and Kobayashi M. GABA (B) receptors accentuate neural excitation contrast in rat insular cortex. Neurosci.2011; 199: 259-271.

30. Gorsane MA, Kebir O, Hache G, et al. Is baclofen a revolutionary medication in alcohol addiction management? Review and recent updates. Subst Abus. 2012;33: 336349.

31. Franchitto N, Pelissier F, Lauque $D$, et al. Self-intoxication with baclofen in alcohol-dependent patients with co-existing psychiatric illness: an emergency department case series. Alcohol Alcohol .2014;49(1): 79-83. 32.Sullivan R, Hodgman MJ, Kao L, et al. Baclofen overdose mimicking brain death. Clin Toxicol. 2012; 50: 141144. 